\title{
Obesity is an independent risk factor for pre-transplant portal vein thrombosis in liver recipients
}

Rosa Ayala ${ }^{1,4^{*}}$, Silvia Grande ${ }^{1}$, Rosalía Bustelos ${ }^{3}$, Carmen Ribera ${ }^{1}$, Alvaro García-Sesma ${ }^{2}$, Carlos Jimenez², Enrique Moreno ${ }^{2}$ and Joaquín Martínez-López ${ }^{1}$

\begin{abstract}
Background: Portal vein thrombosis is a frequent complication in end-stage cirrhosis with a considerable peri-operative risk for liver transplant candidates. We aimed to characterize the pre-transplant portal vein thrombosis in a cohort of liver transplant recipients, and to identify independent risk factors for this complication.

Methods: 380 consecutive primary orthotopic liver transplants were performed in the Digestive Surgery Department of "12 de Octubre" Hospital (Madrid, Spain), between January 2001 and December 2006. The main risk factors considered were smoking, obesity, metabolic disorders, previous immobility, surgery or trauma, nephrotic syndrome, associated tumor, inflammatory disease, neoplasm myeloprolipherative. Furthermore we have reported genetic thrombophilia results for 271 recipients.
\end{abstract}

Results: Sixty-two (16.3\%) patients developed pre-transplant portal vein thrombosis and its presence had no impact in the overall survival of liver recipients. Obesity was the only independent risk factor for pre-transplant portal vein thrombosis.

Conclusion: We recommend close control of cardiovascular factors in patients with liver cirrhosis in order to avoid associated thrombosis.

Keywords: Thrombophilia, Portal vein thrombosis, Liver transplant recipient

\section{Background}

Portal vein thrombosis (PVT) is a well recognized complication in patients with end-stage cirrhosis, and its incidence ranges from 2 to $26 \%$ in different series [1]. PVT has various causes. The cause may be local, such as cirrhosis, primary or metastatic liver cancer, pylephlebitis, vascular abnormalities, and pancreatitis. Alternatively PVT may result from a thrombophilic condition such as myeloproliferative disease, Protein C (PC), Protein S (PS) and Antithrombin (AT) deficiency, or Factor V Leiden and Factor IIG20210A carriers, or a combination of a primary thrombophilia milieu that triggers the formation of the thrombus in the portal circulation [2].

\footnotetext{
* Correspondence: rayaladiaz@hematologia12octubre.com

'Hematology Department, 12 De Octubre University Hospital, Avenida Córdoba s/n, 28041 Madrid, Spain

${ }^{4}$ Complutense De Madrid University, Madrid, Spain

Full list of author information is available at the end of the article
}

PVT continues to be associated with a considerable peri-operative risk for liver transplant candidates [3,4], and is associated with increased operative time, transfusion requirements, re-interventions, and lower survival rate relative to PVT extension [5]. Therefore, PVT has been seen as an obstacle to orthotopic liver transplantation (OLT).

We aimed to identify possible parameters that could lead to PVT in a cohort of liver transplant recipients. The influence of this thrombosis in the survival of liver recipient was also evaluated.

This work is related to our previous publication [6] where we analyzed the post-transplant thrombotic events in a cohort of liver transplant recipients to identify possible parameters that could lead to HAT and could be responsible for graft loss due to thrombosis in a extended thrombophilia study. Our results showed that high fibrinogen and decreased protein $\mathrm{C}$ levels were

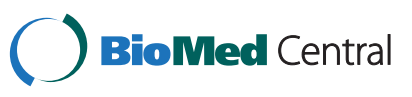


parameters associated with allograft thrombosis. In the present study we analyzed the factors related to portal vein thrombosis in the pre-transplant period and their prognostic implications.

\section{Materials and methods Patient population}

Between January 2001 and December 2006, 380 primary orthotopic liver transplants (OLT) were performed in the Digestive Surgery Department of the 12 de Octubre Hospital (Madrid, Spain). Wherever possible all patients are lab tested for genetic hypercoagulation study irrespective of any presence of thrombophilia. We have reported genetic thrombophilia and JAK2 mutations results for 271 primary OLT recipients. The study was approved by our Institutional Review Board and all patients gave their consent for blood samples to be further processed. Data on thrombophilia risk factors were collected by personal interview, or by reviewing the medical history.

\section{Recipients}

The study population comprised 254 males and 126 females. The cause of liver transplantation was: $18 \mathrm{HBV}$ (hepatitis B virus), $73 \mathrm{HCV}$ (hepatitis C virus), $52 \mathrm{HBV}$ and HCV, 62 Ethanol, 8 Autoimmune, 8 Toxicity, 29 Tumor, $63 \mathrm{HBV}$ or $\mathrm{HCV}$ and tumor, 2 Vascular, 26 Alpha 1 antitrypsin deficits, 24 Biliary atresia and 15 cryptogenetic.

\section{Methods}

\section{Genetic thrombophilia study}

The extracted genomic DNA was processed to detect Factor V Leiden, prothrombin G20210A and methylenetetrahydrofolate (MTHFR) C667T mutations, using realtime PCR (polymerase chain reaction) with hybridization probes in a light-cycler (Roche Diagnostics, Mannheim, Germany).

\section{JAK2 mutations study}

JAK2 V617F ASO quantitative PCR (ASO qPCR) was performed with the ABI PRISM 7900 (Applied Biosystems,
Palo Alto, CA, USA), and a forward ASO primer spanning of the JAK2 V617F mutation region. A reverse primer and MGB TaqMan probe were also employed [7].

\section{Follow-up}

The follow-up period for recipients began on the date of liver transplantation, and ended on the date of death, date of re-transplant, or the end of study (March 1, 2007). Follow-up periods ranged from $15 \mathrm{~d}$ to $6.9 \mathrm{y}$ (median: 20.23 months).

\section{Statistical analyses}

The Pearson's chi-square $\left(\chi^{2}\right)$ statistic and the Student's $t$ test were used to test for differences in the distribution of dichotomous variables, and for differences in the mean values of continuous distributions. Forward stepwise logistic regression was used to identify independent risk factors for PVT. The following variables collected at diagnosis were included in the database: gender (male/ female), age (both as a continuous variable, and grouping patients over and under 16 years of age), the existence of clinical thrombophilia risk factors and the original liver disease.

Overall survival (OS) was calculated from the day of the liver transplantation to death. Kaplan-Meier life tables were constructed for survival data and were compared by means of the log-rank test. A census of the surviving patients was taken on March 1, 2007. Results with a $P$ value less than 0.05 were considered significant.

\section{Results}

Thrombophilia in the study population

Genetic study of thrombophilia.- The prevalence of the heterozygote Factor V Leiden mutation was 7 of 271 (2.6\%), the heterozygote G20210A prothrombin mutation was 13 (4.8\%), and the homozygote C677T MTHFR mutation was 39 (14.9\%). No correlation was observed between pre-transplant PVT and the genetic thrombophilia study (Table 1).

JAK2 mutation in liver recipients.- JAK2 V617F was only detected in four of the 271 primary OLT recipients included in this study, details as follows: one patient

Table 1 Genetic study in association with pre-transplant PVT in liver recipients

\begin{tabular}{|c|c|c|c|}
\hline & $\begin{array}{l}\text { With Pre-transplant } \\
\text { PVT ( } 50 \text { cases) }\end{array}$ & $\begin{array}{l}\text { Without Pre- transplant } \\
\text { PVT ( } 221 \text { cases) }\end{array}$ & Significance \\
\hline \multicolumn{4}{|l|}{ RECIPIENT STUDY } \\
\hline Factor V Leiden mutation ( $\mathrm{N}^{\circ}$ ) (heterozygous) in recipient & $1 / 49$ & $6 / 215$ & $p=0.774$ \\
\hline Prothrombin 20210A mutation ( $\mathrm{N}^{\circ}$ ) (heterozygous) in recipient & $1 / 49$ & $12 / 209$ & $p=0.305$ \\
\hline $\begin{array}{l}\text { C677T MTHFR mutation ( } \mathrm{N}^{\circ} \text { ) (wild type/heterozygous/ } \\
\text { homozygous) in recipient }\end{array}$ & $18 / 23 / 7$ & $87 / 93 / 33$ & $p=0.865$ \\
\hline
\end{tabular}

The study was conducted in 271 liver recipients. The MTHFR C677T genotype was not tested in ten cases. PVT, portal vein thrombosis; MTHFR, 5,10-methylenetetrahydrofolate reductase. 
Table 2 Clinical features of JAK2 V617F positive liver transplant recipients

\begin{tabular}{|c|c|c|c|c|c|c|c|c|c|}
\hline Diagnosis & $\begin{array}{c}\text { JAK2 V617F } \\
\text { Allele burden (\%) }\end{array}$ & Age & Gender & $\begin{array}{c}\text { Hemoglobin } \\
\text { (g/dL) }\end{array}$ & $\begin{array}{l}\text { Hematocrit } \\
(\%)\end{array}$ & $\begin{array}{c}\text { MCV } \\
\text { (fL) }\end{array}$ & $\begin{array}{c}\text { WBC } \\
\text { count } / \mathrm{L}\end{array}$ & $\begin{array}{l}\text { Platelet } \\
\text { count } / \mathrm{L}\end{array}$ & $\begin{array}{l}\text { Follow-up } \\
\text { (months) }\end{array}$ \\
\hline Alcohol cirrhosis and HCV cirrhosis & 6.71 & 62 & M & 13.9 & 39.4 & 93.8 & $5.50 \times 10^{9}$ & $250 \times 10^{9}$ & 48 \\
\hline HCV cirrhosis & 4.25 & 72 & $\mathrm{~F}$ & 10.8 & 35.9 & 84.9 & $5.4 \times 10^{9}$ & $213 \times 10^{9}$ & 60 \\
\hline Budd-Chiari syndrome & 5.65 & 42 & M & 18.7 & 59.1 & 93.4 & $7.1 \times 10^{9}$ & $234 \times 10^{9}$ & 60 \\
\hline Budd-Chiari syndrome and PV & 8.28 & 41 & $\mathrm{~F}$ & 10.3 & 23.7 & 86.7 & $23.7 \times 10^{9}$ & $282 \times 10^{9}$ & 38 \\
\hline
\end{tabular}

$H C V$, hepatitis $C$ virus; $H B V$, hepatitis $B$ virus; PVT, portal vein thrombosis; $M$, male; F, female; $M C V$, mean corpuscular volume; $W B C$, white blood cells; $P V$, polycythemia vera.

diagnosed previously with PV, who presented BuddChiari syndrome (BCS); an other diagnosed with BuddChiari with features of NMP; and two others with neither thrombotic complications nor NMP features (Table 2). Two JAK2 V617F-positive recipients without thrombotic complications did not develop overt MPN after a median follow-up of nearly 4 years.
Pre-transplant PVT in liver recipients and clinical thrombophilia risk factors

Pre-transplant PVT was detected in 62 of 380 primary OLT recipients (16.3\%). In this study population, the primary, clinical, pro-thrombotic risk factor for liver thrombosis is the existence of terminal cirrhosis. In our study, other risk factors associated with thromboses

Table 3 Clinical thrombophilic risk factors in association with pre-transplant PVT cases

\begin{tabular}{|c|c|c|c|}
\hline & $\begin{array}{c}\text { With pre-transplant } \\
\text { PVT }(n=62)\end{array}$ & $\begin{array}{l}\text { Without pre-transplant } \\
\text { PVT }(n=318)\end{array}$ & Significance \\
\hline Child/adult recipient & $2 / 60$ & $48 / 270$ & $p=0.011$ \\
\hline Male/female recipient & $44 / 18$ & 210/108 & $p=0.451$ \\
\hline Associated tumor (Yes/No) & $15 / 32$ & $63 / 133$ & $p=0.951$ \\
\hline Diabetes mellitus and/or high lipid (Yes/No) & $24 / 25$ & $68 / 135$ & $p=0.043$ \\
\hline Inflammatory disease (Yes/No) & $0 / 39$ & 0/183 & $p=N$ \\
\hline Smoking (Yes/No) & $20 / 26$ & $111 / 92$ & $p=0.169$ \\
\hline Inmobility (Yes/No) & $3 / 36$ & $9 / 166$ & $p=0.531$ \\
\hline Surgery Intervention (Yes/No) & $24 / 23$ & 104/103 & $p=0.919$ \\
\hline Obesity (Yes/No) & $5 / 37$ & $4 / 178$ & $p=0.004$ \\
\hline Nephrotic syndrome (Yes/No) & $0 / 39$ & $14 / 163$ & $p=0.069$ \\
\hline Myeloproliferative syndrome (Yes/No) & $2 / 39$ & $0 / 185$ & $p=0.003$ \\
\hline Trauma (Yes/No) & $3 / 37$ & $10 / 171$ & $p=0.631$ \\
\hline Cause of liver transplantation & & & $p=0.135$ \\
\hline $\mathrm{BHV}$ & 2 & 16 & \\
\hline $\mathrm{CHV}$ & 12 & 61 & \\
\hline Ethanol & 14 & 48 & \\
\hline Autoimmune & 3 & 5 & \\
\hline Toxicity & 1 & 7 & \\
\hline Tumor & 7 & 22 & \\
\hline Cryptogenetic & 1 & 14 & \\
\hline Vascular & 2 & 0 & \\
\hline Infrequent (deficit alpha1 antitrypsin) & 3 & 23 & \\
\hline Biliary atresia & 2 & 22 & \\
\hline $\mathrm{BHV}$ and $\mathrm{CHV}$ & 10 & 42 & \\
\hline $\mathrm{BHV}$ and $\mathrm{CHV}$ and Tumor & 5 & 58 & \\
\hline
\end{tabular}

$\mathrm{HCV}$, hepatitis C virus; HBV, hepatitis B virus; PVT, portal vein thrombosis. Data on height was available in 224 of 380 recipients. The body mass index (BMI) was calculated as weight in kilograms/height in meters squared. Obesity was considered when BMI>30 kg/m2. Missing Values: associated tumor (138); DM and/or High lipid (128); Inflammatory disease (158); Smoking (131); Inmobility (166); Surgery Intervention (126); Nephrotic Syndrome (164); Myeloproliferative Syndrome (159); Trauma (159). 
(such as the existence of diabetes or lipid alteration and obesity) were most frequent in the group with pretransplant PVT (24 cases of diabetes or lipid alteration out of 49 with pre-transplant PVT, versus 68 of 203 without pre-transplant PVT, $P=0.043$; and 5 cases of obesity out of 42 with pre-transplant PVT, versus 4 of 182 without pre-transplant thrombotic event, $P=0.004$ ) (see Table 3). Neither the presence of tumour $(P=0.951)$, nor smoking $(P=0.169)$, were associated with pre-transplant PVT. Nevertheless child recipient was less frequent in the group with pre-transplant PVT (2 cases of 62 recipients with PVT, versus 48 of 318 recipients without PVT, $\mathrm{p}=0.011$ ) (Table 3).

\section{Multivariate study}

In the multivariate study, the only variable associated with pre-transplant PVT was obesity (no/yes) (HR 13.2, $P<0.02$ ) (Table 4).

\section{Survival analysis}

Kaplan Meier tests were performed (Figure 1) and the results indicated that pre-transplant PVT was not associated with a poor outcome.

\section{Discussion}

During a liver transplantation, pre-transplant PVT, encountered in approximately $15 \%$ of candidates, increases surgical difficulties and post-operative PV re-thromboses [8]. However, there is no extensive thrombophilia study in a large cohort of liver recipients. In our study, all cases are characterized by the presence of local thrombophilia risk factors: cirrhosis and other factors such as primary cancer, vascular abnormalities. We found obesity as the only clinical factor associated with pre-transplant PVT. Previously obesity has been considered to be a risk factor for the venous thromboembolism as well as arterial

Table 4 Logistic Regression analysis of factors associated with pre-transplant PVT

\begin{tabular}{lcc}
\hline Variable & $\mathbf{p}$ & Hazard Ratio (Cl) \\
\hline AGE (CONTINUOUS VARIABLE) & 0.119 & \\
OBESITY (YES/NO) & $\mathbf{0 . 0 1 6}$ & $\mathbf{1 3 . 1 6 1} \mathbf{( 1 . 3 2 4 - 1 3 0 )}$ \\
ASSOCIATED TUMOR (YES/NO) & 0.756 & \\
LUPUS (YES/NO) & 0.766 & \\
SMOKING (YES/NO) & 0.125 \\
DIABETES MELLITUS AND/OR HIGH & 0.115 \\
LIPID (YES/NO) & \\
CAUSE OF LIVER TRANSPLANTATION & 0.184 \\
FACTOR V LEIDEN & 0.728 \\
PROTHROMBIN 20210A MUTATION & 0.237 \\
MTHFR C677T MUTATION & 0.377 \\
\hline
\end{tabular}

Obesity (no/yes) (HR 14.7, $\mathrm{P}<0.02$ ) was associated with pre-transplant PVT.

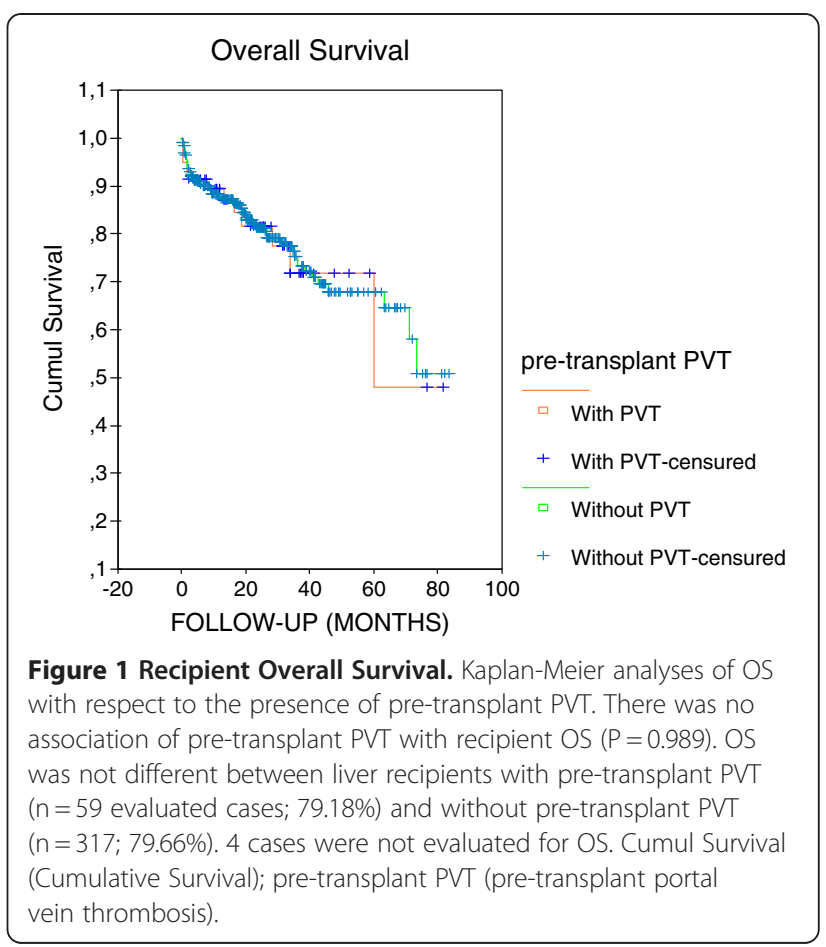

thrombosis [9-15], and was also previously reported as an independent risk factor for clinical decompensation in patients with cirrhosis [16] but it had not been previously associated with PVT. Plausible mechanisms to explain the relation between obesity and venous thrombosis include the existence of a proinflammatory, prothrombotic, and hypofibrinolitic milieu in the obese patients $[12,13]$.

The importance of genetic thrombophilia risk factors in PVT has been investigated in several studies [17-20] but all of them have excluded cases with local risk factors. The incidence of Factor $\mathrm{V}$ Leiden, prothrombin mutation, decreased PC, decreased PS, and decreased AT has been recorded between 3-30\%, 3-22\%, 0-26\%, 2$43 \%$, and $1-26 \%$, respectively. In our study the incidence of Factor V Leiden and prothrombin mutation, was $2.4 \%$ and $4.5 \%$, respectively. The incidence of Factor V Leiden and prothrombin mutations coincide with that seen in the general population and this fact could prove that genetic thrombophilia has no role in pre-transplant PVT in patients with cirrhosis.

JAK2 V617F testing represented an important advance in the diagnostic workup for the recognition of atypical myeloproliferative disease in BCS and PVT patients [21]. Our results do not support the routine screening of JAK2 V617F mutation in patients with splanchnic thrombosis in terminal cirrhosis or malignancy, except when patients have Budd-Chiari syndrome. Our results do not contradict Plessier et al where patients with cirrhosis or malignacy were specifically excluded [22]. 
Unlike previous studies $[3,23,24]$,the presence of pretransplant PVT did not influence the overall survival of recipients. Other authors also reported no significant differences between both groups for 1- to 10-year patient survival [25-28].

\section{Conclusions}

To the best of our knowledge, this is the first extensive genetic thrombophilia study in a large cohort of liver recipients. Obesity and diabetes mellitus and/or hyperlipidaemia were associated with pre-transplant PVT, but obesity was the only independent risk factor for pretransplant PVT. We stress the importance of controlling the cardiovascular factors in patients with liver cirrhosis.

\section{Competing interests}

The authors have no conflicts of interest to declare.

\section{Authors' contributions}

Contribution: RA and JML designed research; SG and RB carried out the molecular genetic studies; RA, JML, AGS, CJ, EM, and CR analyzed and interpreted data; RA designed, performed, and wrote the manuscript; JML supervised the research and critically revised the manuscript. All authors read and approved the final manuscript.

\section{Acknowledgments}

We thank lan Ure for the English review and Sharon Forsyth of Biomedical Editing International for the Editing review; as well the liver transplantation team for the clinic data facility and Jose M. Murallas, Alicia Muñoz, Inmaculada Vidal, Ester Clemente and Pilar Lopez for the patient samples obtained and Dr A. Fuertes for the donor samples stored. We appreciate the advice of Dra T. Toledo and Dra. MA. Martin and the excellent technical assistance of Ana I. Corredor and Paloma Garcia-Tapias.

This work was supported by a grant from Foundation Mutua Madrileña del Automovil (grant 2004/009 and 2008/139).

\section{Author details}

${ }^{1}$ Hematology Department, 12 De Octubre University Hospital, Avenida Córdoba s/n, 28041 Madrid, Spain. ${ }^{2}$ General Surgery Alimentary Tract and Abdominal Organ Transplantation Department, 12 De Octubre University Hospital, Madrid, Spain. ${ }^{3}$ Hematology Department, Sureste Hospital (Arganda), Madrid, Spain. ${ }^{4}$ Complutense De Madrid University, Madrid, Spain.

Received: 6 November 2011 Accepted: 26 July 2012

Published: 21 August 2012

\section{References}

1. Francoz C, Belghiti J, Vilgrain V, Sommacale D, Paradis V, Condat B, Denninger MH, Sauvanet A, Valla D, Durand F: Splanchnic vein thrombosis in candidates for liver transplantation: usefulness of screening and anticoagulation. Gut 2005, 54(5):691-697.

2. Harmanci $O$, Bayraktar $Y$ : Portal hypertension due to portal venous thrombosis: etiology, clinical outcomes. World J Gastroenterol 2007 13(18):2535-2540.

3. Stieber AC, Zetti G, Todo S, Tzakis AG, Fung JJ, Marino I, Casavilla A Selby RR, Starzl TE: The spectrum of portal vein thrombosis in liver transplantation. Ann Surg 1991, 213(3):199-206.

4. Shaked A, Busuttil RW: Liver transplantation in patients with portal vein thrombosis and central portacaval shunts. Ann Surg 1991, 214(6):696-702.

5. Lendoire J, Raffin G, Cejas N, Duek F, Barros Schelotto P, Trigo P, Quarin C, Garay $V$, Imventarza O: Liver transplantation in adult patients with portal vein thrombosis: risk factors, management and outcome. HPB (Oxford) 2007, 9(5):352-356.

6. Ayala R, Martinez-Lopez J, Cedena T, Bustelos R, Jimenez C, Moreno E, Ribera C: Recipient and donor thrombophilia and the risk of portal venous thrombosis and hepatic artery thrombosis in liver recipients. BMC Gastroenterol 2011, 11(1):130.
7. Rapado I, Grande S, Albizua E, Ayala R, Hernandez JA, Gallardo M, Gilsanz F, Martinez-Lopez J: High resolution melting analysis for JAK2 Exon 14 and Exon 12 mutations: a diagnostic tool for myeloproliferative neoplasms. J Mol Diagn 2009, 11(2):155-161.

8. Feng S, Humar A, Pomfret E, Fishbein T, Gaber O: Surgical challenges in transplantation: the Fourth Annual American Society of Transplant Surgeons' State-of-the-Art Winter Symposium. Am J Transplant 2005, 5(3):428-435.

9. Goldhaber SZ, Grodstein F, Stampfer MJ, Manson JE, Colditz GA, Speizer FE, Willett WC, Hennekens $\mathrm{CH}$ : A prospective study of risk factors for pulmonary embolism in women. JAMA 1997, 277(8):642-645.

10. Stein PD, Beemath A, Olson RE: Obesity as a risk factor in venous thromboembolism. Am J Med 2005, 118(9):978-980.

11. Ageno W, Becattini C, Brighton T, Selby R, Kamphuisen PW: Cardiovascular risk factors and venous thromboembolism: a meta-analysis. Circulation 2008, 117(1):93-102.

12. Allman-Farinelli MA: Obesity and venous thrombosis: a review. Semin Thromb Hemost 2011, 37(8):903-907.

13. van Langevelde K, Flinterman LE, van Hylckama Vlieg A, Rosendaal FR, Cannegieter SC: Broadening the factor V Leiden paradox: pulmonary embolism and deep-vein thrombosis as two sides of the spectrum. Blood 2012, 120(5):933-946.

14. Lamattina JC, Foley DP, Fernandez LA, Pirsch JD, Musat Al, D'Alessandro AM, Mezrich JD: Complications associated with liver transplantation in the obese recipient. Clin Transplant 2012, doi:10.1111/j.1399-0012.2012.01669.x. first published on Jun 13

15. Pearson V, Ruzas C, Krebs NF, Goldenberg NA, Manco-Johnson MJ, Bernard TJ: Overweight and Obesity Are Increased in Childhood-Onset Cerebrovascular Disease. J Child Neurol 2012, doi:10.1177/ 0883073812446160. first published on May 30, 2012.

16. Berzigotti A, Garcia-Tsao G, Bosch J, Grace ND, Burroughs AK, Morillas R, Escorsell A, Garcia-Pagan JC, Patch D, Matloff DS, et al: Obesity is an independent risk factor for clinical decompensation in patients with cirrhosis. Hepatology 2011, 54(2):555-561.

17. Egesel T, Buyukasik Y, Dundar SV, Gurgey A, Kirazli S, Bayraktar Y: The role of natural anticoagulant deficiencies and factor $V$ Leiden in the development of idiopathic portal vein thrombosis. J Clin Gastroenterol 2000, 30(1):66-71.

18. Janssen HL, Meinardi JR, Vleggaar FP, van Uum SH, Haagsma EB, van Der Meer FJ, van Hattum J, Chamuleau RA, Adang RP, Vandenbroucke JP, et al: Factor V Leiden mutation, prothrombin gene mutation, and deficiencies in coagulation inhibitors associated with Budd-Chiari syndrome and portal vein thrombosis: results of a case-control study. Blood 2000, 96(7):2364-2368.

19. Primignani M, Martinelli I, Bucciarelli P, Battaglioli T, Reati R, Fabris F, Dell'era A, Pappalardo E, Mannucci PM: Risk factors for thrombophilia in extrahepatic portal vein obstruction. Hepatology 2005, 41(3):603-608.

20. Denninger $M H$, Chait $Y$, Casadevall N, Hillaire S, Guillin MC, Bezeaud A, Erlinger S, Briere J, Valla D: Cause of portal or hepatic venous thrombosis in adults: the role of multiple concurrent factors. Hepatology 2000, 31(3):587-591.

21. Kiladjian JJ, Cervantes F, Leebeek FW, Marzac C, Cassinat B, Chevret S, Cazals-Hatem D, Plessier A, Garcia-Pagan JC, Darwish Murad S, et al: The impact of JAK2 and MPL mutations on diagnosis and prognosis of splanchnic vein thrombosis: a report on 241 cases. Blood 2008, 111(10):4922-4929.

22. Plessier A, Darwish-Murad S, Hernandez-Guerra M, Consigny Y, Fabris F, Trebicka J, Heller J, Morard I, Lasser L, Langlet P, et al: Acute portal vein thrombosis unrelated to cirrhosis: a prospective multicenter follow-up study. Hepatology 2010, 51(1):210-218.

23. Englesbe MJ, Kubus J, Muhammad W, Sonnenday CJ, Welling T, Punch JD, Lynch RJ, Marrero JA, Pelletier SJ: Portal vein thrombosis and survival in patients with cirrhosis. Liver Transp/ 2010, 16(1):83-90.

24. Davidson BR, Gibson M, Dick R, Burroughs A, Rolles K: Incidence, risk factors, management, and outcome of portal vein abnormalities at orthotopic liver transplantation. Transplantation 1994, 57(8):1174-1177.

25. Molmenti EP, Roodhouse TW, Molmenti H, Jaiswal K, Jung G, Marubashi S, Sanchez EQ, Gogel B, Levy MF, Goldstein RM, et al: Thrombendvenectomy for organized portal vein thrombosis at the time of liver transplantation. Ann Surg 2002, 235(2):292-296. 
26. Manzanet G, Sanjuan F, Orbis P, Lopez R, Moya A, Juan M, Vila J, Asensi J, Sendra P, Ruiz J, et al: Liver transplantation in patients with portal vein thrombosis. Liver Transp/ 2001, 7(2):125-131.

27. Dumortier J, Czyglik O, Poncet G, Blanchet MC, Boucaud C, Henry L, Boillot O: Eversion thrombectomy for portal vein thrombosis during liver transplantation. Am J Transplant 2002, 2(10):934-938.

28. Gimeno FA, Calvo J, Loinaz C, Meneu JC, Perez B, Gomez R, Jimenez C, Abradelo M, Moreno A, Sesma A, et al: Comparative analysis of the results of orthotopic liver transplantation in patients with and without portal vein thrombosis. Transplant Proc 2005, 37(9):3899-3903.

doi:10.1186/1471-230X-12-114

Cite this article as: Ayala et al:: Obesity is an independent risk factor for pre-transplant portal vein thrombosis in liver recipients. BMC

Gastroenterology 2012 12:114.

\section{Submit your next manuscript to BioMed Central and take full advantage of:}

- Convenient online submission

- Thorough peer review

- No space constraints or color figure charges

- Immediate publication on acceptance

- Inclusion in PubMed, CAS, Scopus and Google Scholar

- Research which is freely available for redistribution 